\title{
PENGARUH KETERSEDIAAN FITUR LAYANAN DAN KUALITAS PELAYANAN TERHADAP MINAT NASABAH DALAM MENGGUNAKAN BCA MOBILE DI WILAYAH JABODETABEK
}

\author{
Marthauli \\ marthaulpa31@gmail.com \\ R. Elly Mirati \\ ellymirati@yahoo.co.id \\ Rahmanita Vidyasari \\ Rahmanita.vidyasari@akuntansi.pnj.ac.id \\ Program Studi Keuangan dan Perbankan Terapan Politeknik Negeri Jakarta
}

\begin{abstract}
In 2019, the number of BCA mobile banking transactions has increased by $99.2 \%$ and the number of BCA Mobile banking users has increased by $28.57 \%$. This shows that the BCA mobile banking application is accepted by the majority of BCA bank customers, but in fact there are still many complaints from BCA Mobile users. Research aims to understand the effect of Service Feature Availability and Service Quality on Customers Interest in Using BCA Mobile in the Jabodetabek Area. The sample taken is 100 customers of Bank Central Asia. The analyze technique used is multiple linear regression with SPSS Version 26.0. The results shows that the Service Feature Availibility and Service Quality partially effect significantly of interest customers in using BCA Mobile in the Jabodetabek Area. All independent variables, have a joint contribution of $49.2 \%$ to the customers interest in using the BCA Mobile in the Jabodetabek Area.
\end{abstract}

Keywords: Service Feature, Service Quality, Customer Interest, BCA Mobile, Jabodetabek.

\begin{abstract}
ABSTRAK
Pada tahun 2019, jumlah transaksi BCA mobile banking mengalami kenaikan sebesar 99,2\% dan jumlah pengguna BCA mobile banking mengalami kenaikan sebesar 28,57\%. Hal ini menunjukkan bahwa aplikasi BCA mobile banking diterima dan diminati oleh sebagian besar nasabah bank BCA, tetapi kenyataannya masih banyak diterima keluhan dari pengguna BCA Mobile. Penelitian ini bertujuan untuk menganalisis pengaruh ketersediaan fitur layanan dan kualitas pelayanan terhadap minat nasabah dalam menggunakan BCA Mobile di wilayah Jabodetabek Sampel dalam penelitian ini terdiri dari 100 nasabah Bank Central Asia. Teknik analisis yang digunakan adalah regresi linear berganda dengan alat bantu analisis yaitu SPSS Versi 26.0. Hasil penelitian ini menunjukkan bahwa variabel ketersediaan fitur layanan dan kualitas pelayanan secara parsial berpengaruh signifikan terhadap minat nasabah dalam menggunakan BCA Mobile di wilayah Jabodetabek. Seluruh variabel bebas yaitu, ketersediaan fitur layanan dan kualitas pelayanan mempunyai kontribusi secara bersama-sama sebesar 49,2\% terhadap minat nasabah dalam menggunakan BCA Mobile di wilayah Jabodetabek.
\end{abstract}

Kata kunci: Fitur Layanan, Kualitas Pelayanan, Minat Nasabah, BCA Mobile, Jabodetabek.

\section{PENDAHULUAN \\ Latar Belakang}

Perkembangan bank di Indonesia selalu mengikuti perkembangan teknologi yang cepat dan pesat di dunia, sehingga mempengaruhi pola hidup masyarakat, mempengaruhi produk perbankan, dan mempengaruhi sistem layanan perbankan. Dengan adanya perkembangan teknologi informasi yang diadopsi oleh perbankan di Indonesia menyebabkan terjadinya suatu inovasi sehingga bertujuan untuk memudahkan nasabah dalam melakukan transaksi perbankan secara langsung. Salah satu inovasi adalah terjadinya perkembangan layanan setiap bank yang menciptakan layanan transaksi perbankan dengan berbasis teknologi (Electronic transaction) dalam bentuk internet banking, sms banking, dan mobile banking yang dapat digunakan melalui smartphone nasabah.

Mobile banking merupakan salah satu inovasi yang dikeluarkan oleh perbankan untuk memberikan layanan kepada nasabah melalui suatu aplikasi yang dapat digunakan melalui smartphone, dengan tujuan agar nasabah dapat melakukan transaksi keuangan tanpa ada batasan waktu, tanpa harus pergi ke kantor cabang bank dan tanpa melakukan transaksi 
melalui Automatic Teller Machine (ATM). Mobile banking juga diciptakan untuk menghindari masalah yang dialami oleh setiap nasabah dalam melakukan transaksi perbankan yaitu diperlukan waktu minimal \pm 15 menit dalam menunggu antrian di kantor cabang bank dikarenakan kurangnya pegawai bank dan banyaknya nasabah dalam melakukan transaksi keuangan.

Bank BCA merupakan salah satu bank swasta yang menerapkan layanan digital banking. Salah satunya adalah produk mobile banking yang dikenal sebagai BCA mobile dan telah diluncurkan pada tahun 2011. Dengan diluncurkan layanan perbankan melalui smartphone nasabah, pihak Bank BCA mengharapkan nasabahnya dapat menikmati BCA Mobile sebagai layanan perbankan yang cepat dan mudah. Sehingga dalam pengembangan produk digital banking Bank BCA berhasil mendapatkan penghargaan dari Asia Money Awards yang menobatkan Bank BCA memperoleh penghargaan sebagai Best Domestic Bank dan Best Digital Bank tahun 2019 (finansial.bisnis.com/).

Pada tahun 2019 jumlah transaksi BCA mobile banking mengalami kenaikan dari tahun 2018 sebesar 99,2\% (www.bca.co.id) dan jumlah pengguna BCA Mobile banking mengalami kenaikan sebesar 28,57\% (Kontan.co.id). Hal ini menunjukkan bahwa aplikasi BCA mobile banking diterima dan diminati oleh sebagian besar nasabah bank BCA. Melihat fenomena di atas, terjadi kesenjangan kenyataan dan harapan. Sebab para nasabah yang menggunakan BCA Mobile mengakui bahwa aplikasi BCA Mobile masih menerima beberapa keluhan yang dialami oleh para nasabah.

\section{Permasalahan}

Dengan terjadinya fenomena pada tahun 2019, BCA Mobile mengalami keluhan yang dialami oleh pengguna BCA Mobile yaitu terjadinya pembaharuan sistem BCA Mobile yang tidak diberitahukan terlebih dahulu oleh pihak BCA agar nasabah tidak menggunakan aplikasi BCA Mobile dihari itu hingga hari esoknya untuk melakukan transaksi perbankan (cnnindonesia.com) dan nasabah mengeluhkan adanya fitur layanan BCA Mobile yang disediakan belum berjalan optimal, seperti kehadiran fitur pembukaan rekening secara online via aplikasi BCA Mobile, nasabah mengeluhkan fitur layanan tersebut karena ketika nasabah melanjutkan ke tahap verifikasi via video call bersama customer service selalu gagal dan menunggu minimal 7 hari untuk melakukan pembukaan rekening online (kepoindonesia.com)

\section{Tujuan}

Beradasarkan latar belakang dan pertanyaan penelitian di atas, maka tujuan penelitian ini adalah sebagai berikut:

1. Untuk menganalisis pengaruh ketersediaan fitur layanan berpengaruh secara parsial terhadap minat nasabah dalam menggunakan BCA Mobile di wilayah Jabodetabek.

2. Untuk menganalisis pengaruh kualitas pelayanan berpengaruh secara parsial terhadap minat nasabah dalam menggunakan BCA Mobile di wilayah Jabodetabek.

3. Untuk menganalisis pengaruh ketersediaan fitur layanan dan kualitas pelayanan berpengaruh secara simultan terhadap minat nasabah dalam menggunakan BCA Mobile di wilayah Jabodetabek.

\section{TINJAUAN PUSTAKA}

\section{Bauran Pemasaran (Marketing mix)}

Menurut Kotler dan Keller (2016: 62) adanya "4P" dalam kegiatan bauran pemasaran dan dikembangkan menjadi "7P" untuk menyempurnakan jasa sebagai berikut:

1. Product (Produk), elemen dasar dan penting dari bauran pemasaran. Produk ini berupa barang dan jasa

2. Price (Harga), banyak dan sedikitnya jumlah uang yang dikeluarkan konsumen untuk mendapatkan suatu produk

3. Promotion (Promosi), semua kegiatan yang dilakukan oleh perusahaan untuk memperkenalkan, menginformasikan, dan mengingatkan suatu produk atau jasa kepada pasar sasaran.

4. Place (Tempat), dalam melakukan berbagai kegiatan yang dilakukan oleh perusahaan untuk membuat produknya mudah diperoleh dan tersedia pada konsumen sasaran.

5. People (Orang), hal ini terjadi dalam proses seleksi, pelatihan, dan pemotivasian karyawan yang nantinya dapat digunakan sebagai pembedaan perusahaan dalam memenuhi kepuasan pelanggan.

6. Physical Evidence (Bukti fisik), Wujud nyata yang ditawarkan kepada pelanggan ataupun calon pelanggan

7. Process (Proses), sebuah mekanisme dan aktivitas dengan tujuan memasarkan produk barang atau jasa kepada pelanggan. 


\section{Produk}

Produk merupakan elemen dasar dan penting dari bauran pemasaran. Produk diciptakan untuk memenuhi kebutuhan dan memuaskan keinginan konsumen. Kualitas produk merupakan salah satu faktor dalam membentuk persaingan diantara perusahaan untuk menawarkan produknya kepada konsumen.

Menurut Kotler dan Keller (2016:391) suatu produk dapat diklasifikasikan, yaitu:

1. Barang tidak tahan lama (Nondurable goods), barang berwujud yang biasanya habis dikonsumsi dalam satu atau beberapa kali pemakaian.

2. Barang tahan lama (Durable goods), barang berwujud yang biasanya bisa bertahan lama dengan banyak pemakaian (umur ekonomis pemakaian normal adalah satu tahan lebih).

3. Jasa, aktivitas manfaat atau kepuasan yang ditawarkan oleh penjual untuk dijual dan dikonsumsi oleh pihak lain.

Menurut David Garvin dalam buku

Fandy Tjiptono (2016:134) kualitas produk memiliki delapan dimensi sebagai berikut:

1. Performance (kinerja), merupakan karakteristik operasi pokok dari produk inti (core product) yang dibeli.

2. Features (fitur atau ciri-ciri tambahan), yaitu karaktersitik sekunder atau pelengkap

3. Reliability, yaitu kemungkinan kecil mengalami kerusakan atau gagal dipakai oleh pengguna.

4. Confermance to Specifications, yaitu sejauh mana karakteristik desain dan operasi memenuhi standar-standar yang telah ditetapkan sebelumnya.

5. Durability (daya tahan), yaitu berkaitan dengan berapa lama produk tersebut dapat digunakan.

6. Serviceability, hal ini meliputi kecepatan, kompetensi, kenyamanan, kemudahan direparasi; serta penanganan keluhan secara memuaskan.

7. Esthetics (Estetika), yaitu terjadinya daya tarik suatu produk terhadap panca indera.

8. Perceived Quality (kualitas yang dipersepsikan), yaitu citra dan reputasi produk serta tanggung jawab perusahaan terhadapnya.

Jasa

Karakteristik dari perusahaan jasa menurut

Soemohadiwidjojo (2017:10), yaitu:

1. Tidak Berwujud (Intangibility), produk jasa memiliki sifat tidak berwujud atau tidak dapat dilihat sebelum adanya transaksi pembelian.

2. Tidak terpisahkan (Inseparability), produk jasa diproduksi dan dikonsumsi oleh penyedia jasa tersebut.

3. Bervariasi (Variability), jenis dan kualitas jasa yang diberikan berbeda-beda untuk setiap konsumen, karena jasa tersebut sangat bergantung kepada siapa yang memberikan jasa serta kapan, dan dimana jasa tersebut dilakukan kepada konsumen.

4. Mudah lenyap (Perishability), karena jasa itu sifatnya nonfisik, produk jasa tidak dapat disimpan dan harus segera dikonsumsi pada saat pelanggan memperolehnya.

\section{Fitur Layanan}

Menurut Kotler \& Keller (2012:8) fitur merupakan karakteristik produk yang menjadi pelengkap fungsi dasar produk.

Menurut Poon (2008:56), terdapat indikator ketersediaan fitur pada suatu $e$ banking, yaitu kemudahan akses informasi tentang produk dan jasa, keberagaman layanan transaksi, keberagaman fitur, dan inovasi produk.

\section{Kualitas Pelayanan}

Menurut Tjiptono (2012:157), kualitas pelayanan adalah ukuran seberapa bagus tingkat layanan yang diberikan mampu sesuai dengan ekspektasi pelanggan.

Menurut Tjiptono (2012) Dimensi Kualitas Pelayanan, yaitu:

1. Reliability, yaitu kemampuan untuk melaksanakan pelayanan yang telah dijanjikan dengan segera, akurat, dan memuaskan dengan cara meminimalisir kesalahan sekecilpun.

2. Assurance atau jaminan/keyakinan, yaitu pengetahuan dan kemampuan karyawan untuk meyakinkan pelanggan atas pelayanan yang diberikan.

3. Kriteria Tangible atau bukti berwujud, yaitu pelayanan yang diberikan kepada pelanggan secara nyata dan dapat dilihat oleh pelanggan. Seperti, fasilitas fisik, perlengkapan, dan lain-lainnya.

4. Empathy atau empati, yaitu pelayanan yang diberikan kepada nasabah secara pribadi, istimewa dan adanya kemudahan dalam melakukan hubungan dengan konsumen, sehingga menciptakan hubungan yang baik.

5. Responsiveness atau daya tanggap, yaitu melakukan pelayanan kepada pelanggan 
secara sigap dan cepat, yang diberikan kepada setiap pelanggan.

\section{Minat Nasabah}

Menurut Sadirman (2011:76) minat merupakan suatu kondisi yang terjadi apabila seseorang melihat ciri-ciri atau arti sementara situasi yang dihubungkan dengan keinginankeinginan atau kebutuhan-kebutuhannya sendiri.

Minat penggunaan mobile banking dikatakan berhasil jika jumlah penggunanya semakin meningkat setiap waktu dan layanan pada mobile banking terus digunakan oleh penggunanya. Dalam terjadinya kegiatan minat ulang menggunakan online banking dapat dilihat dari seberapa sering nasabah menggunakan fasilitas yang diberikan oleh pihak bank dalam melakukan transaksi perbankan secara online melalui layanan mobile banking (Setyanto, 2011).

\section{Penelitian Terdahulu}

Dalam melakukan penelitian yang berjudul "Pengaruh Ketersediaan Fitur Layanan dan Kualitas Pelayanan Terhadap Minat Nasabah Dalam BCA Mobile di Wilayah Jabodetabek" perlu dilakukan analisis terhadap penelitian-penelitian yang sudah dilakukan sebelumnya. Menurut Ahmad dan Pambudi (2014) Ketersediaan Fitur Terhadap Minat Ulang Nasabah Menggunakan Internet Banking BRI, menyatakan hasil bahwa variabel fitur layanan memiliki pengaruh yang signifikan terhadap minat nasabah menggunakan internet banking dan menurut Rithmaya (2016) pengaruh fitur layanan berpengaruh signifikan terhadap minat nasabah Bank BCA dalam menggunakan internet banking. Hal ini terjadi karena dengan fitur layanan merupakan faktor utama bagi nasabah untuk memenuhi kebutuhan nasabah dalam melakukan transaksi perbankan. Menurut Bulkia, Herawati, Hasanah (2019) Pengaruh kualitas layanan secara simultan berpengaruh terhadap minat pengguna internet banking Banjarmasin. Hal ini terjadi karena semakin baik layanan yang diberikan maka semakin mempengaruhi minat nasabah dalam menggunakan internet banking.

\section{Kerangka berpikir}

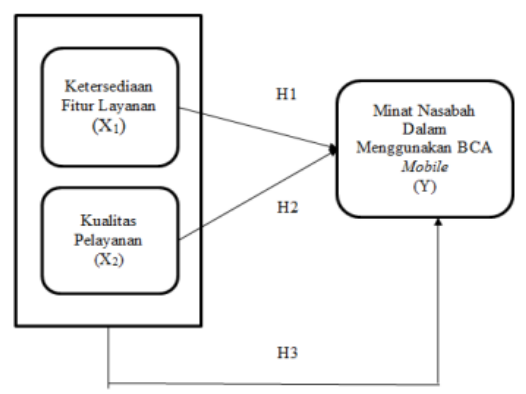

Gambar 1 Kerangka berpikir

Sumber : data diolah penulis, 2020

\section{METODE PENELITIAN}

Jenis penelitian yang digunakan adalah penelitian deskriptif dengan pendekatan kuantitatif. Penelitian deskriptif adalah suatu metode penelitian yang ditujukan untuk menggambarkan fenomena-fenomena yang ada, yang berlangsung pada saat ini atau saat yang lampau. Pendekatan kuantitatif dilakukan dengan melakukan desain penelitian dalam menggunakan angka-angka dan instrumen yang digunakan dalam penelitian kuantitatif biasanya menggunakan kuesioner/angket.

Populasi pada penelitian ini adalah nasabah Bank BCA yang menggunakan aplikasi BCA mobile banking di wilayah Jabodetabek. Dalam penelitian ini, teknik yang digunakan dalam menentukan sampel adalah purposive sampling. Adapun rumus yang digunakan untuk mengukur sampel dalam penelitian ini, menggunakan rumus Widiyanto (2015), sehingga diperoleh dengan perhitungan berjumlah 97 responden. Untuk memudahkan penelitian maka jumlah sampel ditetapkan sebanyak 100 responden.

Analisis data yang digunakan dalam penelitian ini adalah analisis regresi linear berganda, uji ini dilakukan setelah melakukan uji asumsi klasik. Uji asumsi klasik merupakan salah satu syarat sebelum melakukan uji pada regresi linear berganda yang terdiri dari yakni uji normalitas, uji multikolinearitas, dan uji heteroskedastisitas. Kemudian dilanjutkan dengan melakukan uji hipotesis, yang terdiri dari uji $\mathrm{t}$ (parsial) dan uji F (simultan). Setelah itu melakukan uji koefisien determinasi $\left(\mathrm{R}^{2}\right)$ untuk mengetahui besar pengaruh variabel independen terhadap variabel dependen. Sebelum dilakukan analisis data, terlebih dahulu dilakukan uji coba instrumen data yang terdiri dari uji validitas dan uji reliabilitas. Uji Validitas bertujuan untuk menilai valid atau tidaknya suatu kuesioner. Sedangkan, Uji reliabilitas bertujuan untuk mengukur 
kestabilan ukuran dan konsistensi jawaban responden pada kuesioner.

HASIL DAN PEMBAHASAN

Uji Instrumen Data

1. Uji Validitas

Tabel 1 Hasil Uji Validitas

\begin{tabular}{|c|c|c|c|c|}
\hline $\begin{array}{c}\text { Vari } \\
\text { abel }\end{array}$ & $\begin{array}{c}\text { Indikat } \\
\text { or }\end{array}$ & $\begin{array}{c}\text { r- } \\
\text { hitung }\end{array}$ & r-tabel & Ket \\
\hline \multirow{4}{*}{$(\mathrm{X} 1)$} & $\mathrm{X} 1.1$ & 0,639 & 0,361 & Valid \\
\cline { 2 - 5 } & $\mathrm{X} 1.2$ & 0,787 & 0,361 & Valid \\
\cline { 2 - 5 } & $\mathrm{X} 1.3$ & 0,806 & 0,361 & Valid \\
\cline { 2 - 5 } & $\mathrm{X} 1.4$ & 0,625 & 0,361 & Valid \\
\hline \multirow{5}{*}{$(\mathrm{X} 2)$} & $\mathrm{X} 2.1$ & 0,548 & 0,361 & Valid \\
\cline { 2 - 5 } & $\mathrm{X} 2.2$ & 0,735 & 0,361 & Valid \\
\cline { 2 - 5 } & $\mathrm{X} 2.3$ & 0,872 & 0,361 & Valid \\
\cline { 2 - 5 } & $\mathrm{X} 2.4$ & 0,723 & 0,361 & Valid \\
\cline { 2 - 5 } & $\mathrm{X} 2.5$ & 0,876 & 0,361 & Valid \\
\hline \multirow{4}{*}{$(\mathrm{Y})$} & $\mathrm{Y} .1$ & 0,758 & 0,361 & Valid \\
\cline { 2 - 5 } & $\mathrm{Y} .2$ & 0,605 & 0,361 & Valid \\
\cline { 2 - 5 } & $\mathrm{Y} .3$ & 0,811 & 0,361 & Valid \\
\cline { 2 - 5 } & $\mathrm{Y} .4$ & 0,791 & 0,361 & Valid \\
\hline
\end{tabular}

Sumber: data diolah penulis, 2020

Berdasarkan tabel 1 dapat diketahui bahwa seluruh item pertanyaan kuesioner yang digunakan memiliki $\mathrm{r}$ hitung $>\mathrm{r}$ tabel yang berarti bahwa setiap item pertanyaan atas kuesioner telah dinyatakan valid. Hal ini menunjukkan bahwa setiap item pertanyaan penelitian dalam kuesioner dapat mengukur sesuatu yang akan diukur setiap variabel dan item pertanyaan dapat digunakan untuk penelitian selanjutnya.

\section{Uji Reliabilitas}

Tabel 2 Hasil Uji Reliabilitas

\begin{tabular}{|c|c|c|c|}
\hline Variabel & $\begin{array}{c}\text { Cron } \\
\text { bach's } \\
\text { Alpha }\end{array}$ & $\begin{array}{c}\text { Cronbach } \\
\text { 's Alpha } \\
\text { Standar }\end{array}$ & Ket \\
\hline$(\mathrm{X} 1)$ &, 677 & 0,60 & Reliabel \\
\hline$(\mathrm{X} 2)$ &, 827 & 0,60 & Reliabel \\
\hline$(\mathrm{Y})$ &, 723 & 0,60 & Reliabel \\
\hline
\end{tabular}

Sumber: data diolah penulis, 2020

Berdasarkan pada tabel 2 dapat diketahui bahwa bahwa seluruh item pertanyaan kuesioner yang digunakan memiliki Cronbach's Alpha > 0, 6 yang berarti bahwa setiap item pertanyaan yang digunakan dalam penelitian adalah reliabel dan setiap item pertanyaan penelitian dalam kuesioner dapat diandalkan karena jawaban atas pertanyaan variabel stabil.

\section{Uji Asumsi Klasik}

\section{Uji Normalitas}

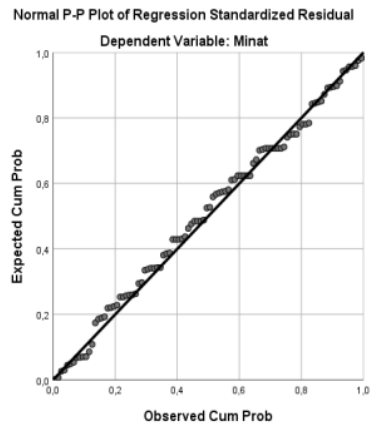

Gambar 2 grafik probability plot

Sumber: data diolah penulis, 2020

Pada gambar 2 yaitu hasil uji statistik normalitas ini, didukung oleh hasil uji statistik melalui uji grafik probability plot, yang menggambarkan bahwa data menyebar disekitar garis diagonal dan mengikuti arah garis diagonal.

Tabel 3 Hasil Uji Normalitas

\begin{tabular}{|c|c|c|}
\hline \multicolumn{3}{|c|}{ One-Sample Kolmogorov-Smirnov Test } \\
\hline & & $\begin{array}{c}\text { Unstandardized } \\
\text { Residual }\end{array}$ \\
\hline \multicolumn{2}{|l|}{$\mathrm{N}$} & 100 \\
\hline \multirow{2}{*}{$\begin{array}{l}\text { Normal } \\
\text { Parameters }{ }^{\mathrm{a}} \\
\mathrm{b}\end{array}$} & Mean &, 0000000 \\
\hline & $\begin{array}{l}\text { Std. } \\
\text { Deviation }\end{array}$ & 1,66059370 \\
\hline \multirow{3}{*}{$\begin{array}{l}\text { Most } \\
\text { Extreme } \\
\text { Differences }\end{array}$} & Abso & ,050 \\
\hline & Posi &, 043 \\
\hline & Negative &,- 050 \\
\hline \multicolumn{2}{|c|}{ Test Statistic } & 050 \\
\hline \multicolumn{2}{|c|}{ Asymp. Sig. (2-tailed) } & $200^{\mathrm{c}, \mathrm{c}}$ \\
\hline
\end{tabular}

Sumber: data diolah penulis, 2020

Dapat dilihat dari tabel 3 Hasil uji normalitas melalui uji statistik yaitu uji Kolmogrov-Sminov memenuhi kriteria, yaitu memiliki hasil sebesar 0,200>0,05. Maka dinyatakan bahwa data berdistribusi normal.

\section{Uji Multikolinearitas}

Tabel 4 Hasil Uji Multikolinearitas

\begin{tabular}{|c|c|c|}
\hline \multirow{2}{*}{ Model } & \multicolumn{2}{|c|}{ Collinearity Statis } \\
\cline { 2 - 3 } & Tolerance & VIF \\
\hline $\begin{array}{c}\text { Ketersediaan Fitur } \\
\text { Layanan (X1) }\end{array}$ &, 708 & 1,413 \\
\hline $\begin{array}{c}\text { Kualitas Pelayanan } \\
\text { (X2) }\end{array}$ &, 708 & 1,413 \\
\hline
\end{tabular}

Sumber : data diolah penulis, 2020

Pada tabel 4 hasil uji multikolinearitas menunjukkan bahwa model regresi penelitian bebas multikolinearitas, yang ditunjukkan melalui hasil tolerance semua variabel yang lebih besar 0,10 dengan nilai 0,708 (X1) dan 0,708 (X2). Sementara nilai VIF (Variance 
Inflation Factor) semua variabel berada dibawah 10 yaitu 1,413 (X1) dan 1,413 (X2).

\section{Uji Heteroskedastisitas}

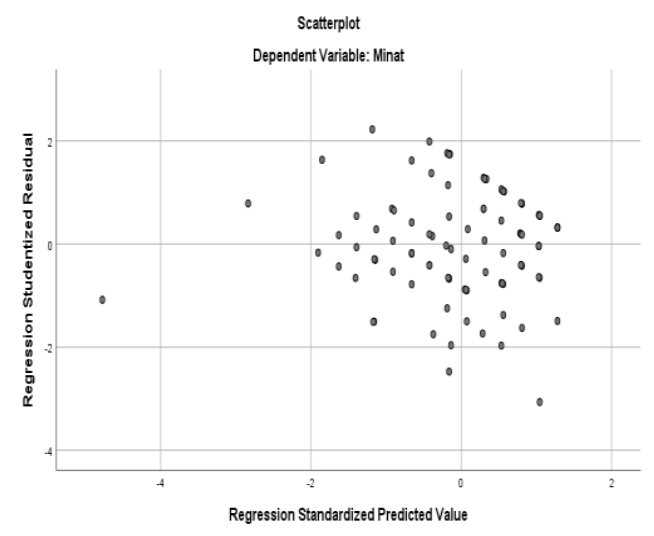

Gambar 3 Hasil Uji grafik scatter plot Sumber: data diolah penulis, 2020

Berdasarkan gambar 2 terlihat bahwa penyebaran titik-titik terbentuk secara acak, tidak membentuk pola serta penyebarannya berada di atas maupun di bawah angka 0 pada sumbu Y.

\begin{tabular}{|c|c|}
\multicolumn{1}{c}{ Tabel 5 Hasil Uji Glejser } \\
Model & Sig. \\
\hline (Constant) &, 050 \\
\hline $\begin{array}{c}\text { Ketersediaan Fitur Layanan } \\
\text { (X1) }\end{array}$ &, 361 \\
\hline Kualitas Pelayanan (X2) &, 628 \\
\hline
\end{tabular}

Sumber : data diolah penulis, 2020

Selain menggunakan scatter plot untuk uji heteroskedastisitas kemudian dilanjutkan menggunakan uji glejser untuk memperkuat uji heteroskedastisitas, dapat dilihat pada tabel 5 yang ditunjukan bahwa semua variabel memiliki nilai signifikansi lebih dari 5\%, diketahui nilai signifikansi (Sig.) untuk variabel ketersediaan fitur layanan (X1) sebesar 0,361 dan untuk variabel kualitas pelayanan (X2) sebesar 0,628. Maka dapat disimpulkan bahwa model regresi ini tidak terjadi heteroskedastisitas.

\section{Analisis Regresi Linear Berganda}

Untuk hasil persamaan linear berganda dijabarkan melalui hasil berikut:

Tabel 6 Hasil Uji Regresi Linear Berganda

\begin{tabular}{|c|c|c|}
\hline \multirow{2}{*}{ Model } & \multicolumn{2}{|c|}{$\begin{array}{c}\text { Unstandardized } \\
\text { Coefficients }\end{array}$} \\
\cline { 2 - 3 } & $\mathrm{B}$ & Std. Error \\
\hline (Constant) & 3,619 & 1,435 \\
\hline $\begin{array}{c}\text { Ketersediaan Fitur } \\
\text { Layanan (X1) }\end{array}$ &, 386 &, 088 \\
\hline
\end{tabular}

(X2)

Sumber: data diolah penulis, 2020

Berdasarkan tabel 6 maka dapat

diperoleh persamaan sebagai berikut:

\section{$\mathrm{Y}=3,619+0,386 \mathrm{X} 1+0,407 \mathrm{X} 2+\mathrm{e}$}

Analisis hasil uji dapat dinyatakan sebagai berikut:

1. Nilai konstanta merupakan besarnya nilai dari variabel terikat (Y) tanpa adanya pengaruh dari variabel independen lainnya (X). Hasil uji regresi menunjukkan nilai konstanta sebesar 3,619, yang artinya besar satuan Minat Nasabah dalam menggunakan BCA Mobile di wilayah Jabodetabek (Y) tanpa adanya pengaruh variabel Ketersediaan Fitur Layanan (X1) dan Kualitas Pelayanan (X2) adalah sebesar 3,619.

2. Koefisien regresi untuk variabel Ketersediaan Fitur Layanan (X1) menunjukkan nilai positif sebesar 0,386. Nilai koefisien yang positif menunjukkan bahwa variabel Ketersediaan Fitur Layanan (X1) memiliki pengaruh positif terhadap variabel Minat Nasabah dalam menggunakan BCA Mobile di wilayah Jabodetabek (Y) dengan asumsi variabel bebas lain konstan, artinya jika variabel pengaruh Ketersediaan Fitur Layanan (X1) meningkat, maka minat nasabah dalam menggunakan BCA Mobile pun meningkat sebesar 0,386 .

3. Koefisien regresi untuk variabel Kualitas Pelayanan (X2) menunjukkan nilai positif sebesar 0,407. Jabodetabek (Y) dengan asumsi variabel bebas lain konstan, artinya jika variabel pengaruh Kualitas Pelayanan (X2) meningkat, minat nasabah dalam menggunakan BCA Mobile pun meningkat sebesar 0,407.

4. Nilai e merupakan nilai eror atau nilai dari variabel lain yang mempengaruhi variabel minat nasabah dalam menggunakan BCA Mobile di wilayah Jabodetabek (Y) yang tidak ditelti pada penelitian ini.

\section{Uji t (parsial)}

Tabel 7 Hasil Uji t (parsial)

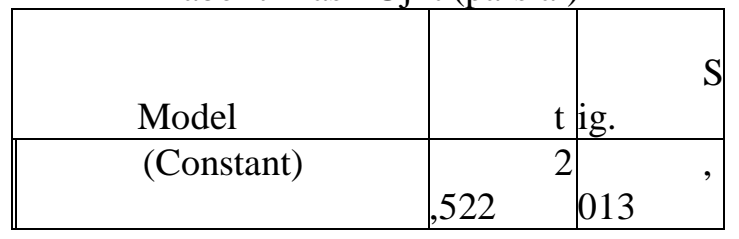


Account: Vol 8 No 1 Marthauli. R. Elly Mirati. Rahmanita Vidyasari

\begin{tabular}{||c|cc|c|}
\hline $\begin{array}{c}\text { Ketersediaan Fitur } \\
\text { Layanan (X1) }\end{array}$ & 4 & \\
\hline Kualitas &, 366 & & 000 \\
Pelayanan (X2) & & 4 & \\
\hline
\end{tabular}

Sumber : data diolah penulis, 2020

Berdasarkan tablel 7, maka hasil uji t dapat dianalisis sebagai berikut:

a. Ketersediaan Fitur Layanan (X1) terhadap Minat Nasabah dalam menggunakan BCA Mobile di wilayah Jabodetabek (Y)

Berdasarkan hasil pengujian, dapat diperoleh nilai t hitung sebesar 4,366 lebih besar dari t tabel 1,985 $(4,366>1,985)$ dan dari tabel diatas tersebut juga dapat dilihat bahwa nilai signifikansi lebih kecil dari 0,05 yaitu sebesar $0,00(0,00<0,05)$. Hal tersebut menyatakan bahwa variabel ketersediaan fitur layanan berpengaruh secara parsial terhadap minat nasabah dalam menggunakan BCA Mobile di wilayah Jabodetabek.

b. Kualitas Pelayanan (X2) terhadap Minat Nasabah dalam menggunakan BCA Mobile di wilayah Jabodetabek (Y)

Berdasarkan hasil pengujian, dapat diperoleh nilai t hitung sebesar 4,925 lebih besar dari t tabel 1,985 (4,925>1,985) dan dari tabel tersebut juga dapat dilihat bahwa nilai signifikansi lebih kecil dari 0,05 yaitu sebesar $0,00(0,00<0,05)$. Hal tersebut menyatakan bahwa variabel kualitas pelayanan berpengaruh secara parsial terhadap minat nasabah dalam menggunakan BCA Mobile di wilayah Jabodetabek.

\section{Uji F (simultan)}

Tabel 8 Hasil Uji F (simultan)

\begin{tabular}{|c|c|c|}
\hline Model & F & sig. \\
\hline Regression & 47,001 &, $000^{\mathrm{b}}$ \\
\hline Residual & & \\
\hline Total & & \\
\hline
\end{tabular}

Sumber: data diolah penulis, 2020

Berdasarkan tabel 8, dapat diperoleh nilai $\mathrm{F}$ hitung lebih besar dari $\mathrm{F}$ tabel $(47,001$ $>3,09$ ) dan dari tabel tersebut juga dapat dilihat bahwa nilai signifikansi $(0,00<0,05)$. Hal tersebut menyatakan bahwa variabel ketersediaan fitur layanan dan kualitas pelayanan berpengaruh secara simultan terhadap minat nasabah dalam menggunakan BCA Mobile di wilayah Jabodetabek.

\section{Uji Koefisien Determinasi}

Tabel 9 Hasil Uji Koefisien Determinasi

\begin{tabular}{|c|c|c|}
\hline Model & R & R Square \\
\hline 1 &, $702^{\text {a }}$ &, 492 \\
\hline \multicolumn{2}{|l}{ Sumber: data diolah penulis, 2020}
\end{tabular}

Berdasarkan tabel 9 dapat dilihat bahwa dari hasil uji tersebut diperoleh nilai $\mathrm{R}$ Squre sebesar 0,492 atau 49,2\% yang berarti Ketersediaan Fitur Layanan (X1) dan Kualitas Pelayanan (X2) dalam mempengaruhi minat nasabah dalam menggunakan BCA Mobile di wilayah Jabodetabek sebesar 49,2\% sedangkan sisanya dipengaruhi oleh variabel lain yang tidak dijelaskan dalam penelitian.

\section{PEMBAHASAN}

Pengaruh Ketersediaan Fitur
Terhadap Minat Nasabah
Menggunakan BCA Mobile di $\begin{array}{r}\text { Dalam } \\ \text { Wilayah }\end{array}$
$\begin{aligned} & \text { Jabodetabek } \\ & \text { Berdasarkan hasil penelitian ini, }\end{aligned}$ variabel ketersediaan fitur layanan berpengaruh positif signifikan terhadap minat nasabah dalam menggunakan BCA Mobile di wilayah Jabodetabek. Pengaruh tersebut dikarenakan adanya indikator ketersediaan fitur layanan sebagai pelengkap layanan mobile banking dengan tujuan agar nasabah dapat menggunakan layanan perbankan dengan praktis dan cepat dalam melakukan transaksi perbankan. Hasil dalam penelitian ini mendukung dalam teori fitur pada bauran pemasaran, yang dimana fitur ini merupakan suatu produk yang menjadi pelengkap dari fungsi dasar layanan yang dikembangkan melalui teknologi. Menurut penelitian terdahulu Ahmad dan Pambudi (2014) juga menegaskan bahwa dengan adanya penambahan fitur-fitur baru yang dapat memenuhi segala kebutuhan nasabah untuk melakukan transaksi secara online.

\section{Pengaruh Kualitas Pelayanan Terhadap Minat Nasabah Dalam Menggunakan BCA Mobile di Wilayah Jabodetabek}

Berdasarkan hasil penelitian ini, variabel kualitas pelayanan berpengaruh positif signifikan terhadap minat nasabah dalam menggunakan BCA Mobile. Hal tersebut dikarenakan kualitas pelayanan merupakan faktor penting untuk mempengaruhi minat nasabah, dapat memenuhi kebutuhan dan keinginan nasabah. Hal ini sesuai dengan teori kualitas pelayanan, yang dimana kualitas pelayanan memberikan dorongan kepada pelanggan untuk menghasilkan hubungan baik 
dengan nasabahnya, sehingga memungkinkan perusahaan memahami dengan seksama harapan dan kebutuhan nasabah.

\section{Pengaruh Ketersediaan Fitur Layanan dan Kualitas Pelayanan Terhadap Minat Nasabah Dalam Menggunakan BCA Mobile di Wilayah Jabodetabek}

Berdasarkan hasil penelitian ini, variabel fitur layanan dan kualitas pelayanan secara simultan berpengaruh positif signifikan terhadap minat nasabah dalam menggunakan BCA Mobile di wilayah Jabodetabek. Dengan adanya ketersediaan fitur layanan BCA Mobile yang beragam dan memudahkan nasabah dalam melakukan transaksi perbankan akan menarik minat nasabah dalam menggunakan BCA Mobile. Kemudian dengan adanya kualitas pelayanan juga akan meningkatkan minat nasabah dalam menggunakan BCA Mobile seperti pegawai andal dalam pekerjaannya, dapat menyelesaikan keluhan nasabah atas BCA Mobile, dan membantu nasabahnya dalam mengaktifkan BCA Mobile secara tuntas.

\section{KESIMPULAN}

Berdasarkan hasil dan pembahasan penelitian yang berjudul "Ketersediaan Fitur Layanan dan Kualitas Pelayanan Terhadap Minat Nasabah Dalam Menggunakan BCA Mobile di Wilayah Jabodetabek" maka dapat diambil kesimpulan sebagi berikut:

1. Hasil analisis variabel ketersediaan fitur layanan berpengaruh positif dan signifikan terhadap minat nasabah dalam menggunakan BCA Mobile di wilayah Jabodetabek. Hal ini menunjukkan bahwa dengan tersedianya layanan transaksi yang beranekaragam, aplikasi BCA Mobile mudah digunakan oleh nasabah, dan pihak bank BCA juga menyempurnakan aplikasi terus menerus merupakan hal yang sangat dipertimbangkan dalam menggunakan aplikasi BCA Mobile bagi nasabah. Dengan ketersediaan fitur layanan yang lengkap dan sesuai dengan kebutuhan nasabah dalam melakukan transaksi perbankan maka nasabah berminat dalam menggunakan BCA Mobile di wilayah Jabodetabek.

2. Hasil analisis variabel kualitas pelayanan berpengaruh positif dan signifikan terhadap minat nasabah dalam menggunakan BCA Mobile di wilayah Jabodetabek. Hal ini menunjukkan bahwa nasabah merasakan pegawai BCA membantu nasabah dalam menggunakan BCA Mobile dan bersedia melayani masalah mengenai BCA Mobile. Kualitas pelayanan yang diberikan semakin baik maka nasabah berminat dalam menggunakan BCA Mobile di wilayah Jabodetabek.

3. Variabel ketersediaan fitur layanan dan kualitas pelayanan secara simultan berpengaruh signifikan terhadap minat nasabah dalam menggunakan BCA Mobile di wilayah Jabodetabek. Hal ini membuat terjadinya peningkatkan minat dalam menggunakan BCA Mobile pada nasabah Bank BCA. Dengan ketersediaan layanan transaksi yang beragam dan melakukan inovasi dengan penyempurnaan aplikasi. Begitu juga dengan dengan adanya pemberian kualitas pelayanan pegawai Bank BCA yang baik kepada nasabah bank BCA juga akan meningkatkan minat menggunakan BCA Mobile di wilayah Jabodetabek.

\section{KETERBATASAN}

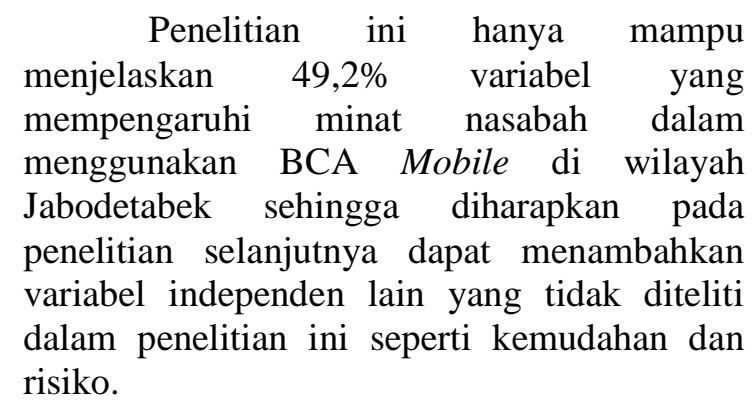

\section{DAFTAR PUSTAKA}

Ahmad, Pambudi. (April 2014). Pengaruh Persepsi Manfaat, Persepsi Kemudahan, Keamanan dan Ketersediaan Fitur Terhadap Minat Ulang Nasabah Bank Dalam Menggunakan Internet Banking (Studi Pada Program Layanan Internet Banking BRI). Jurnal Studi Manajemen, Vol. 8, No. 1, hlm. 1-11.

Bulkia, Herawati, Hasanah. (2019). Pengaruh Pengetahuan Nasabah dan Kualitas Layanan Terhadap Minat Individu Pengguna Internet Banking Banjarmasin. Jurnal Ilmiah Manajemen, Vol. 3, No. 2, hlm. 90-97.

Garvin, David A. alih bahasa Fandy Tjiptono, 2016. Strategi. Yogyakarta: Andi Offset

Kotler, Philip and Kevin Lane Keller, 2016. Marketing Management, 15th Edition, Pearson Education, Inc. 
Poon. (2008). Users' Adoption of e-banking Services: The Malaysian Perspective. Journal of Business \& Industrial Marketing, Vol. 23, hlm.59-69.

Rithmaya. (2016). Pengaruh Kemudahan Penggunaan, Kemanfaatan, Sikap, Risiko, dan Fitur Layanan Terhadap Minat Ulang Nasabah Bank BCA Dalam Menggunakan Internet Banking. Journal of Research in
Economics and Management, Vol 16, No. 1, hlm. 160- 177.

Sadirman. 2011. Interaksi dan Motivasi Belajar Mengajar. Jakarta : PT Rajagrafindo

Soemohadiwidjojo. 2017. Key Performance Indicator untuk Perusahaan Industri. Jakarta: Raih Asa Sukses (RAS).

Tjiptono, Fandy (2012). Pemasaran Jasa. Yogyakarta: Andi Offset. 